\title{
Studies on Epiphytic Microflora on Apple (Malus domestica Borkh.) Fruits and Leaves
}

\author{
Aqleema Banoo*, Efath Shahnaz, Saba Banday, Rovidha S. Rasool and Taibah Bashir
}

Division of Plant Pathology, Sher-e-kashmir University of Agriculture Science and Technology of Kashmir, Shalimar Campus, Srinagar 190025, India

*Corresponding author

K e y w o r d s
Apple,
Epiphytes,
Isolation,
Methods

Keywords

Apple,

Epiphytes,

Isolation,

Methods

Article Info

Accepted:

17 June 2020

10 July 2020

\section{A B S T R A C T}

The present study was undertaken with an objective to estimate predominant epiphytes from leaves and fruits of apple by using different methods on different media. In all, eleven epiphytes were isolated using potato dextrose agar, nutrient agar and yeast maltose agar media. Amongst them, five fungal isolates viz., Aspergillus sp. ( $\left.\mathrm{I}_{1}\right)$, Penicillium sp. $\left(\mathrm{I}_{2}\right)$, Fusarium sp. $\left(\mathrm{I}_{3}\right)$, Rhizopus sp. $\left(\mathrm{I}_{4}\right)$ and Alternaria sp. $\left(\mathrm{I}_{5}\right)$ and six bacterial isolates viz., Pseudomonas sp. ( $\left.\mathrm{I}_{6}\right)$, Pseudomonas sp. $\left(\mathrm{I}_{7}\right)$, Bacillus sp. $\left(\mathrm{I}_{8}\right)$, Bacillus sp. $\left(\mathrm{I}_{9}\right)$, Staphylococcus sp. $\left(\mathrm{I}_{10}\right)$ and Micrococcus sp. $\left(\mathrm{I}_{11}\right)$ were predominantly noticed under all the three methods (leaf impression, serial dilution and fruit washing) and were hence, used for further studies. The highest average colony count of 3.62 colonies $/ \mathrm{cm}^{2}$ was recorded in fruit washing method followed by leaf impression (3.17) and lowest in serial dilution method (2.12).

\section{Introduction}

Apple (Malus domestica Borkh.) is one of the important temperate fruit crops in world. It belongs to family Rosaceae and sub family Pomoidae and has originated in temperate region between Black Sea and Caspian Sea (Bal, 2006). Plant associated fungi and bacteria isolated from rhizoplane and phylloplane surfaces are called as epiphytes
(Andrews and Harris, 2000). The epiphytic microorganisms are the microorganisms that are naturally present on the surfaces of fruits and vegetables, and can be isolated to be used for the control of postharvest pathogens as naturally occurring antagonists (Janisiewicz, 1987; Sobiczewski et al., 1996). Bacteria are the dominant microbial inhabitants of the phyllosphere, occurring in concentrations of $10^{2}$ to $10^{12}$ cells/gram of leaf, although 
archaea, filamentous fungi and yeasts may also be important (Whipps et al., 2008). The epiphytic microorganisms existing on fruits and leaves of fruit trees were the object of studies conducted by Janisiewicz and Roitman (1988), Wisniewski and Wilson (1992), Sobiczewski and Bryk (1995). Janisiewicz et al., (2001) reported the feasibility of using mixtures of bacterial and yeast antagonists for the control of $P$. expansum on apples and observed an increment in the control of blue mould by mixtures of yeasts with different nutritional profiles. He also reported that the mechanism by which microbial antagonists suppress the postharvest pathogens is still unknown, but competition for nutrients and space, production of antibodies, direct parasitism, and induced resistance are most widely accepted modes of their action. In another research, Manso and Nunes (2011) isolated epiphytic microorganism (Metschnikowia andauensis) from the surface of leaves of different pome and citrus fruits. Studies on the phylloplane micro flora of safflower by Mandhare and Suryawanshi (2009) revealed that the bacterial population was more than that of fungi in both the cultivars of Bhima and NARI-NHH-2 at various growth stages viz., seedling, flowering and physiological maturity stages of crop. He also reported that the mean fungal population was highest at flowering stage $\left(5.32 \times 10^{2} / \mathrm{cm}^{2}\right.$ leaf area), whereas, the bacterial population was more at physiological maturity $\left(32.15 \times 10^{2} / \mathrm{cm}^{2}\right.$ leaf area). Fungal and bacterial populations were highest on phylloplane of cultivar 'Bhima'. studies on phylloplane micro-organisms as bio-control agents for postharvest disease management is lacking. Hence, keeping in view the above facts, present investigation shall be undertaken with the following objectives: To estimate predominant epiphytes from leaves and fruits of apple by using different methods on different media.

\section{Materials and Methods}

\section{Estimation of predominant epiphytes from leaves and fruits of apple}

\section{Collection of leaf and fruit samples}

For the estimation of epiphytes, an orchard at Harwan, which had not been treated with fungicides for the last five years was selected. A group of seven trees, centrally located in the apple orchard was sampled. Fifty leaves were collected randomly from each tree, bulked, composited and taken immediately to the laboratory in sterilized perforated polythene bags for further studies. By using leaf area meter (Systronics leaf area meter 211) surface area of each leaf was measured and the average leaf area was expressed in $\mathrm{cm}^{2}$. Similarly, fifty healthy blemish-free apple fruits were collected randomly from each apple tree in sterilized perforated polythene bags and brought to the laboratory for further studies. Length and diameter of collected healthy fruits were measured with the help of a digital Vernier caliper and an average fruit length and diameter were expressed in centimeters $(\mathrm{cm})$.

\section{Isolation of epiphytes by leaf impression method}

The composited and selected leaves were washed with sterilized 70 distilled water in order to remove dirt and dust and were air dried. Dorsal and ventral surface of each leaf was pressed momentarily against the surface of potato dextrose agar plates at three places separately. The plates were properly labeled and incubated in an inverted position at $24 \pm 2{ }^{\circ} \mathrm{C}$ for fungi and $26 \pm 2^{\circ} \mathrm{C}$ for bacteria for 3 days. The similar process was repeated with nutrient agar media and yeast agar media plates. The emergence and development of colonies was counted after every 24 hours (Aneja,2004). Colonies of bacteria, 
actinomycetes and fungi per centimeter square of leaf was calculated by using the formula:

Colonies $/ \mathrm{cm}^{2}=$ Total No. of colonies $/$ Leaf area

\section{Isolation of epiphytes by serial dilution method}

Five discs, each of $5 \mathrm{~mm}$ diameter were cut from every leaf using a sterile $5 \mathrm{~mm}$ cork borer. A total of 250 leaf discs were obtained, transferred to $100 \mathrm{ml}$ of sterilized distilled water and stirred for 20 minutes till a suspension was obtained. The contents were shaken for uniform distribution of the cell/spores and $0.1 \mathrm{ml}$ of aliquots from $10^{-1}$ and $10^{-2}$ dilutions using a sterile pipette were transferred to each sterile plates containing potato dextrose agar, nutrient agar, yeast maltose agar medium using L-shaped spreader. The plates were properly labeled and incubated at $24 \pm 2^{\circ} \mathrm{C}$ for fungi and $26 \pm 2^{\circ} \mathrm{C}$ for bacteria in an inverted position. The development of colonies was monitored and counted after every 24 hours for three days (Mukhtar et al., 2010). Microbial population $/ \mathrm{cm}^{2}$ was calculated by applying the formula (Aneja, 2004):

Propagules $/ \mathrm{cm}^{2}=$

Total No. of spores in $0.1 \mathrm{ml} \times 100$

Total area of 250 discs $\times 2$

(Area of one leaf disc $=\pi \mathrm{r} 2$, where $\mathrm{r}$ is the radius of the disc in $\mathrm{cm}$ )

\section{Isolation of epiphytes by fruit washing method}

For isolation of epiphytes from fruits, selected fruit were dipped individually in a container of $150 \mathrm{ml}$ sterile water and shaken for 20 minutes on a mechanical shaker at $250 \mathrm{rpm}$, to break free the micro-organisms. Each fruit was washed twice. The contents were shaken for uniform distribution of the cell/spores and $0.1 \mathrm{ml}$ of aliquots from $10^{-1}$ dilutions using a sterile pipette was transferred to sterile plates containing potato dextrose agar medium, yeast maltose agar medium and $10^{-2}$ dilution was transferred to nutrient agar medium. Same procedure was repeated for second washing. The plates were properly labelled and incubated at $24 \pm 2^{\circ} \mathrm{C}$ for fungi and $26 \pm 2^{\circ} \mathrm{C}$ for bacteria. The development of colonies was monitored and counted after every $24 \mathrm{hrs}$. Microbial population $/ \mathrm{cm}^{2}$ of fruit surface was calculated by applying the formula (Aneja, 2004):

Propagules $/ \mathrm{cm}^{2}=$

Total No. of colonies in $0.1 \mathrm{ml} \times 150$

Total area of apple fruit surface

(Area of apple fruit surface $=4 \pi r^{2}$, where $r$ is the radius of the disc in $\mathrm{cm}$ )

\section{Identification}

The fungal colonies obtained were studied for colony characters, such as colony colour, margin, aerial growth and microscopic observations with respect to nature of mycelium, spore bearing structure, spore shape etc. The features of all the isolates were compared with the description in the standard manuals (Chowdhry et al., (2000); Barnett and Hunter 1972).

The bacterial colonies were grown at $26 \pm 2{ }^{\circ} \mathrm{C}$ for 24 hours on specific media viz., NA and King's B medium slants or plates. The colony morphology was studied on plates after streaking a loop full of isolated colony. The bacterial isolates were Gram stained and slides observed under Gaynor microscope at 100X magnification. Cell shape, size, Gram reaction was observed and photographed 
(Gerhardt 1981). The bacterial cultures were examined for various morphological, biochemical and physiological characteristics as per the procedure described in Bergey's manual of Determinative Bacteriology (Holts et al., 1994).

\section{Results and Discussion}

\section{Isolation and identification of epiphytes}

Five fungal isolates of epiphytes viz., Aspergillus sp. ( $\left.\mathrm{I}_{1}\right)$, Penicillium sp. $\left(\mathrm{I}_{2}\right)$, Rhizopus sp. ( $\left.\mathrm{I}_{4}\right)$, Fusarium sp. $\left(\mathrm{I}_{3}\right)$, and Alternaria sp. $\left(\mathrm{I}_{5}\right)$ were isolated from leaf and fruit surface using three different methods (Plate 1) and isolates were identified on the basis of their morphological characteristics which were compared with authenticated descriptions (Chowdhry et al., (2000); Burnett and Hunter, 1972). Six bacterial epiphytes viz., Pseudomonas sp. ( $\mathrm{I}_{6}$ and $\left.\mathrm{I}_{7}\right)$, Bacillus sp. $\left(\mathrm{I}_{8}\right.$ and $\left.\mathrm{I}_{9}\right)$, Staphylococcus sp. $\left(\mathrm{I}_{10}\right)$ and Micrococcus sp. $\left(\mathrm{I}_{11}\right)$ were isolated. For identification purposes, morphological and biochemical characters of these isolates were studied as per the procedures described by Holt et al., (1994).

\section{Estimation of predominant epiphytes by leaf impression method}

The mean populations (Table I) of all microbial isolates viz., $\mathrm{I}_{1}, \mathrm{I}_{2}, \mathrm{I}_{3}, \mathrm{I}_{4}, \mathrm{I}_{7}, \mathrm{I}_{9}, \mathrm{I}_{10}$ and $\mathrm{I}_{12}$ on PDA $\left(0.40\right.$ colonies per $\left.\mathrm{cm}^{2}\right)$ and YMA media $\left(0.40\right.$ colonies $\left./ \mathrm{cm}^{2}\right)$ were significantly at par, but significantly different from NA media $\left(0.34\right.$ colonies per $\left.\mathrm{cm}^{2}\right)$. However, a comparison of different media revealed that the microbial count of $\mathrm{I}_{9}(1.03$ colonies per $\mathrm{cm}^{2}$ ) was highest on YMA, of $\mathrm{I}_{7}$ $\left(0.95\right.$ colonies per $\left.\mathrm{cm}^{2}\right)$ on $\mathrm{NA}$ and of $\mathrm{I}_{10}$ $\left(0.90\right.$ colonies per $\left.\mathrm{cm}^{2}\right)$ on PDA. The mean number of colonies was highest in case of $\mathrm{I}_{7}$ (0.92 colonies per $\left.\mathrm{cm}^{2}\right)$ and differed significantly from $\mathrm{I}_{9}\left(0.63\right.$ colonies per $\left.\mathrm{cm}^{2}\right)$ and others $\left(0.53\right.$ colonies per $\left.\mathrm{cm}^{2}\right)$. The lowest mean numbers of colonies were recorded in case of $\mathrm{I}_{3}$, followed by $\mathrm{I}_{4}$ and $\mathrm{I}_{1}$ (0.02, 0.03 and 0.29 colonies per $\mathrm{cm}^{2}$ respectively).

\section{Estimation of predominant epiphytes by serial dilution method}

Perusal of the data presented in Table II revealed that the mean number of colonies of microbial isolates on PDA media was 0.20 per $\mathrm{cm}^{2}$ which was significantly at par with the number of colonies on YMA (0.19 colonies per $\mathrm{cm}^{2}$ ) but significantly differed from NA $\left(0.41\right.$ colonies per $\left.\mathrm{cm}^{2}\right)$. However, a comparison of different media revealed that the microbial count of $\mathrm{I}_{6}(0.92$ colonies per $\left.\mathrm{cm}^{2}\right)$ was highest on NA media, of $\mathrm{I}_{6}(0.42$ colonies per $\left.\mathrm{cm}^{2}\right)$ on PDA media and of $\mathrm{I}_{7}$ $\left(0.40\right.$ colonies per $\left.\mathrm{cm}^{2}\right)$ on YMA media. The mean number of colonies significantly differed and was highest in case of $\mathrm{I}_{6}(0.55$ colonies per $\left.\mathrm{cm}^{2}\right)$ followed by $\mathrm{I}_{7}(0.50$ colonies per $\left.\mathrm{cm}^{2}\right)$ and $\mathrm{I}_{8}(0.40$ colonies per $\mathrm{cm}^{2}$ ). The lowest mean numbers of colonies were recorded in case of $\mathrm{I}_{3}$ followed by $\mathrm{I}_{2}$ and $\mathrm{I}_{1}$ i.e. $0.02,0.100 .14$ colonies per $\mathrm{cm}^{2}$ of leaf.

Estimation of predominant epiphytes by fruit washing method

A perusal of the data presented in Table III revealed that the mean number of colonies of microbial isolates on PDA medium was 0.50 per $\mathrm{cm}^{2}$. In case of YMA medium, the mean number of colonies of microbial isolates was 0.47 colonies per $\mathrm{cm}^{2}$. While as, on NA medium, the mean number of colonies of microbial isolates was 0.44 colonies $/ \mathrm{cm}^{2}$ of leaf. However, a comparison of different media revealed that the microbial count of $\mathrm{I}_{8}$ (0.98 colonies per $\mathrm{cm}^{2}$ ) was highest on NA medium, $\mathrm{I}_{1}\left(0.91\right.$ colonies per $\left.\mathrm{cm}^{2}\right)$ on PDA medium and 0.81 colonies per $\mathrm{cm}^{2}$ on YMA medium. The mean number of colonies 
significantly differed and were highest in case of $\mathrm{I}_{6}\left(0.86\right.$ colonies $\left./ \mathrm{cm}^{2}\right)$ followed by $\mathrm{I}_{9}(0.79$ colonies per $\left.\mathrm{cm}^{2}\right)$ and $\mathrm{I}_{1}(0.57$ colonies per $\mathrm{cm}^{2}$ ). The lowest number of colonies were recorded in case of $\mathrm{I}_{3}\left(0.03\right.$ colonies per $\left.\mathrm{cm}^{2}\right)$ followed by $\mathrm{I}_{2}\left(0.30\right.$ colonies per $\left.\mathrm{cm}^{2}\right)$ and $\mathrm{I}_{8}$ $\left(0.32\right.$ colonies per $\left.\mathrm{cm}^{2}\right)$.

Table.1 Microbial count of major epiphytes from apple phylloplane by leaf impression method

\begin{tabular}{|c|c|c|c|c|c|}
\hline \multirow{2}{*}{\multicolumn{2}{|c|}{ Microbial isolates }} & \multirow{2}{*}{\multicolumn{4}{|c|}{ No. of colonies $/ \mathrm{cm}^{2}$}} \\
\hline & & & & & \multirow{2}{*}{$\begin{array}{c}\text { Overall mean } \\
0.29(0.538) \\
\end{array}$} \\
\hline $\mathbf{I}_{1}$ & Aspergillus sp. & $\begin{array}{l}\text { PDA } \\
\text { Medium } \\
0.42(0.648)\end{array}$ & $\begin{array}{l}\text { YMA } \\
\text { Medium } \\
0.35(0.591)\end{array}$ & $\begin{array}{l}\text { NA } \\
\text { Medium } \\
0.12(0.346)\end{array}$ & \\
\hline $\mathbf{I}_{2}$ & Penicillium sp. & $0.54(0.734)$ & $0.41(0.460)$ & $0.00(0.000)$ & $0.31(0.556)^{d}$ \\
\hline $\mathbf{I}_{3}$ & Fusarium sp. & $0.06(0.244)$ & $0.00(0.000)$ & $0.00(0.000)$ & $0.02(0.414)^{a}$ \\
\hline $\mathbf{I}_{4}$ & Rhizopus sp. & $0.03(0.173)$ & $0.04(0.200)$ & $0.03(0.173)$ & $0.03(0.173)^{b}$ \\
\hline $\mathbf{I}_{7}$ & Pseudomonas sp. & $0.86(0.927)$ & $0.97(0.984)$ & $0.95(0.974)$ & $0.92(0.959)^{g}$ \\
\hline $\mathbf{I}_{9}$ & Bacillus sp. & $0.00(0.000)$ & $1.03(1.014)$ & $0.87(0.932)$ & $0.63(0.793)^{f}$ \\
\hline $\mathbf{I}_{10}$ & Staphylococcus sp. & $0.90(0.948)$ & $0.00(0.000)$ & $0.44(0.663)$ & $0.44(0.663)^{e}$ \\
\hline \multicolumn{2}{|c|}{ Mean } & $0.40(0.524)^{B}$ & $0.40(0.464)^{B}$ & $0.34(0.441)^{A}$ & \\
\hline
\end{tabular}

$\mathrm{CD}(\mathrm{P} \leq 0.05)$ Isolate $(\mathrm{I})=0.004$, Media $(\mathrm{M})=0.002$ Isolate $\times$ Media $=0.007$

Figures in brackets are square root transformed values.

Table.2 Microbial count of major epiphytes from apple phylloplane by serial dilution method

\begin{tabular}{|c|c|c|c|c|c|}
\hline \multirow{2}{*}{\multicolumn{2}{|c|}{ Microbial isolates }} & \multirow{2}{*}{\multicolumn{4}{|c|}{ No. of colonies $/ \mathrm{cm}^{2}$}} \\
\hline & & & & & \\
\hline $\mathbf{I}_{1}$ & Aspergillus sp. & $\begin{array}{l}\text { PDA } \\
\text { Medium } \\
0.20(0.447)\end{array}$ & $\begin{array}{l}\text { YMA } \\
\text { Medium } \\
0.22(0.469)\end{array}$ & $\begin{array}{l}\text { NA } \\
\text { Medium } \\
0.0(0.000)\end{array}$ & $\begin{array}{l}\text { Overall } \\
\text { mean } \\
0.14 \\
(0.374)^{c}\end{array}$ \\
\hline $\mathbf{I}_{2}$ & Penicillium sp. & $0.22(0.469)$ & $0.10(0.316)$ & $0.0(0.000)$ & $\begin{array}{l}0.10 \\
(0.316)^{b}\end{array}$ \\
\hline $\mathbf{I}_{3}$ & Fusarium sp. & $0.0(0.000)$ & $0.08(0.282)$ & $0.0(0.000)$ & $0.02(0.141)^{a}$ \\
\hline $\mathbf{I}_{4}$ & Rhizopus sp. & $0.42(0.648)$ & $0.31(0.558)$ & $0.92(0.951)$ & $0.55(0.741)^{g}$ \\
\hline $\mathbf{I}_{7}$ & Pseudomonas sp. & $0.25(0.500)$ & $0.40(0.632)$ & $0.86(0.927)$ & $\begin{array}{l}0.50 \\
(0.707)\end{array}$ \\
\hline I9 & Bacillus sp. & $0.35(0.591)$ & $0.24(0.489)$ & $0.61(0.781)$ & $\begin{array}{l}0.40 \\
(0.632)^{e}\end{array}$ \\
\hline $\mathbf{I}_{10}$ & Staphylococcus sp. & $0.0(0.000)$ & $0.0(0.000)$ & $0.49(0.700)$ & $\begin{array}{l}0.16 \\
(0.400)\end{array}$ \\
\hline \multicolumn{2}{|c|}{ Mean } & $0.20(0.379)^{A}$ & $0.19(0.392)^{A}$ & $0.41(0.479)^{B}$ & \\
\hline
\end{tabular}

$\mathrm{CD}(\mathrm{P} \leq 0.05)$ Isolate $(\mathrm{I})=0.003$ Media $(\mathrm{M})=0.002$ Isolate $\times$ Media $=0.006$

Figures in brackets are square root transformed values. 
Table.3 Microbial count of major epiphytes from apple fruits by fruit washing method

\begin{tabular}{|c|c|c|c|c|c|}
\hline \multirow{2}{*}{\multicolumn{2}{|c|}{ Microbial isolates }} & \multirow{2}{*}{\multicolumn{4}{|c|}{ No. of colonies $/ \mathrm{cm}^{2}$}} \\
\hline & & & & & \\
\hline $\mathbf{I}_{1}$ & Aspergillus sp. & $\begin{array}{l}\text { PDA Medium } \\
0.91(0.953)\end{array}$ & $\begin{array}{l}\text { YMA } \\
\text { Medium } \\
0.81(0.900)\end{array}$ & $\begin{array}{l}\text { NA } \\
\text { Medium } \\
0.0(0.000)\end{array}$ & $\begin{array}{l}\text { Overall } \\
\text { mean } \\
0.57(0.754)\end{array}$ \\
\hline $\mathbf{I}_{2}$ & Penicillium sp. & $0.47(0.685)$ & $0.45(0.670)$ & $0.0(0.000)$ & $0.30(0.547)^{b}$ \\
\hline $\mathbf{I}_{3}$ & Fusarium sp. & $0.0(0.000)$ & $0.11(0.331)$ & $0.0(0.000)$ & $0.03(0.173)^{a}$ \\
\hline $\mathbf{I}_{4}$ & Rhizopus sp. & $0.73(0.854)$ & $0.51(0.714)$ & $0.0(0.000)$ & $0.41(0.640)^{d}$ \\
\hline $\mathbf{I}_{7}$ & Pseudomonas sp. & $0.67(0.818)$ & $0.80(0.894)$ & $1.13(1.060)$ & $0.86(0.927)^{\mathrm{g}}$ \\
\hline $\mathbf{I}_{9}$ & Bacillus sp. & $0.0(0.000)$ & $0.0(0.000)$ & $0.98(0.989)$ & $0.32(0.565)^{c}$ \\
\hline $\mathbf{I}_{10}$ & Staphylococcus sp. & $0.73(0.854)$ & $0.62(0.787)$ & $1.02(1.009)$ & $0.79(0.888)^{f}$ \\
\hline \multicolumn{2}{|c|}{ Mean } & $0.50(0.594)^{B}$ & $0.47(0.613){ }^{C}$ & $0.44(0.436)^{A}$ & \\
\hline
\end{tabular}

$\mathrm{CD}(\mathrm{P} \leq 0.05)$ Isolate $(\mathrm{I})=0.003$ Media $(\mathrm{M})=0.002$ Isolate $\times$ Media $=0.006$

Figures in brackets are square root transformed values.

Plate.1 Isolation of epiphytes by using different methods
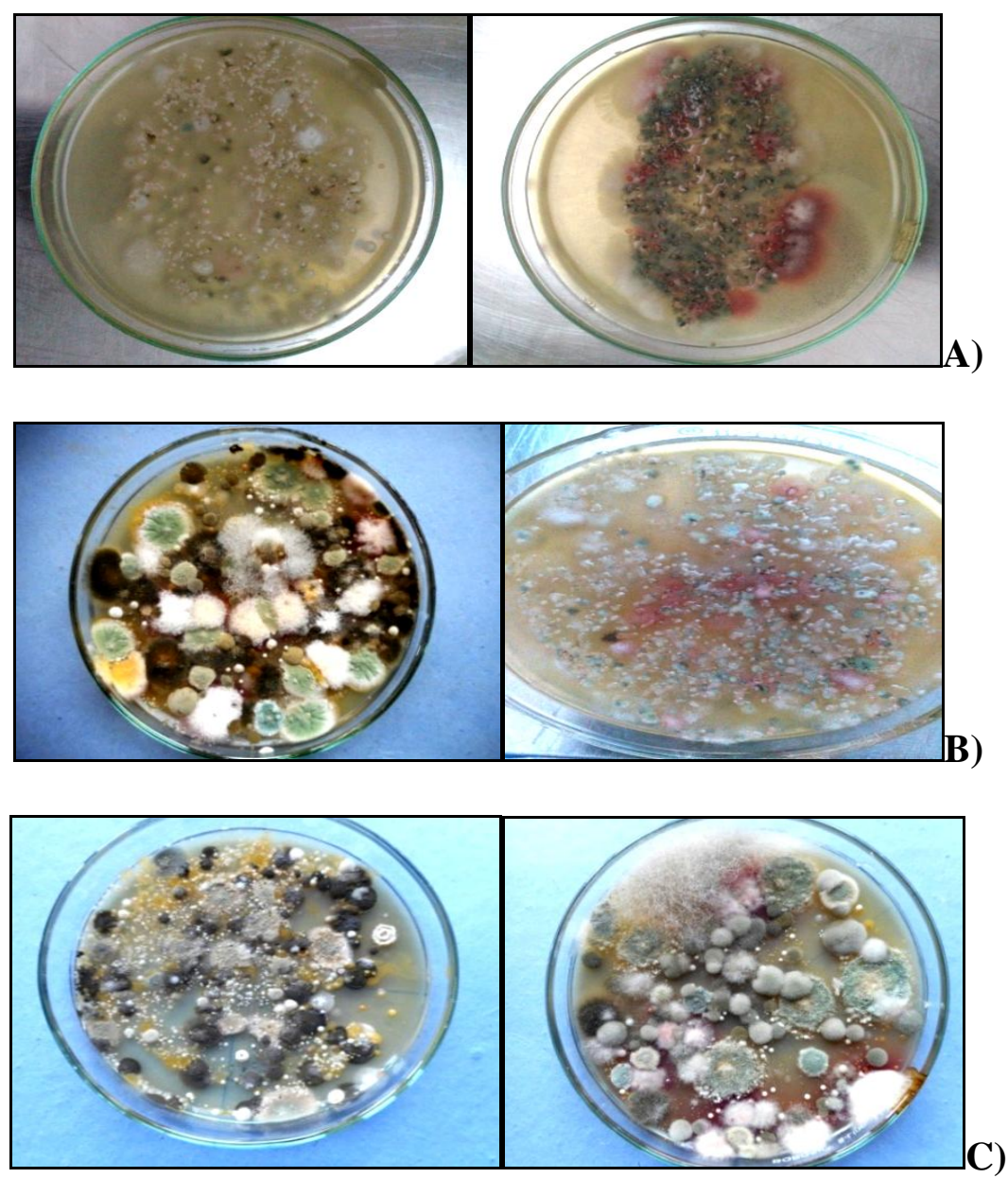
Figure.1 Graphical representation of microbes (No. of colonies $/ \mathrm{cm}^{2}$ ) from apple phylloplane by leaf impression method

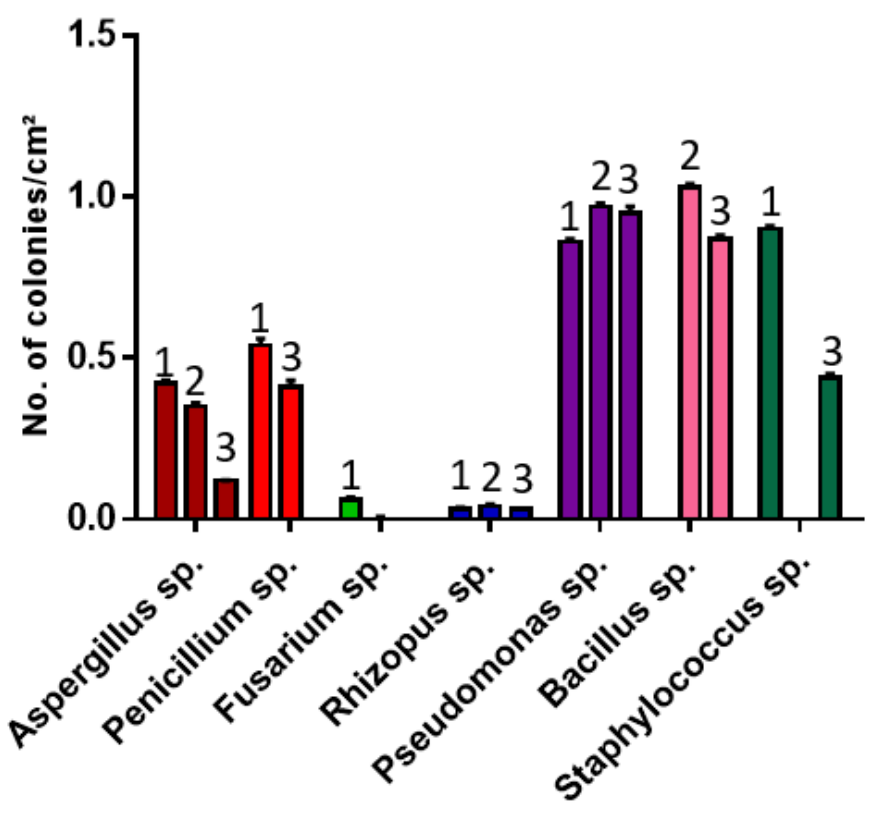

1. PDA

2. YMA

3. NA

Microbial isolates

Figure.2 Graphical representation of microbes (No. of colonies $/ \mathrm{cm}^{2}$ ) from apple phylloplane by leaf impression method

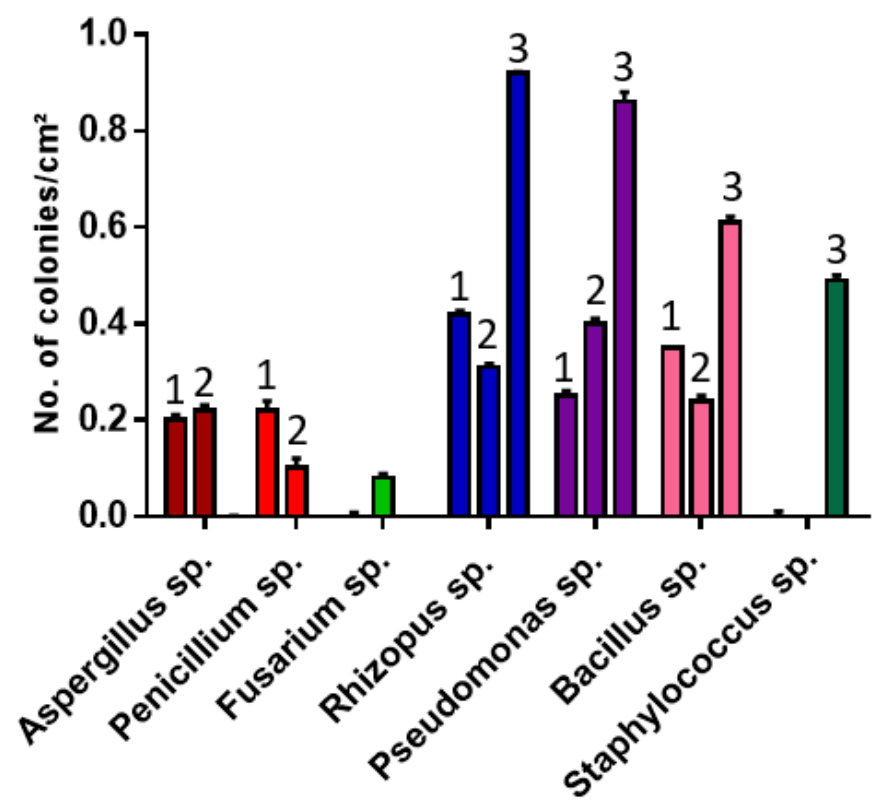

1. PDA

2. YMA

3. NA

Microbial isolates 
Figure.3 Graphical representation of microbes (No. of colonies $/ \mathrm{cm}^{2}$ ) from apple phylloplane by

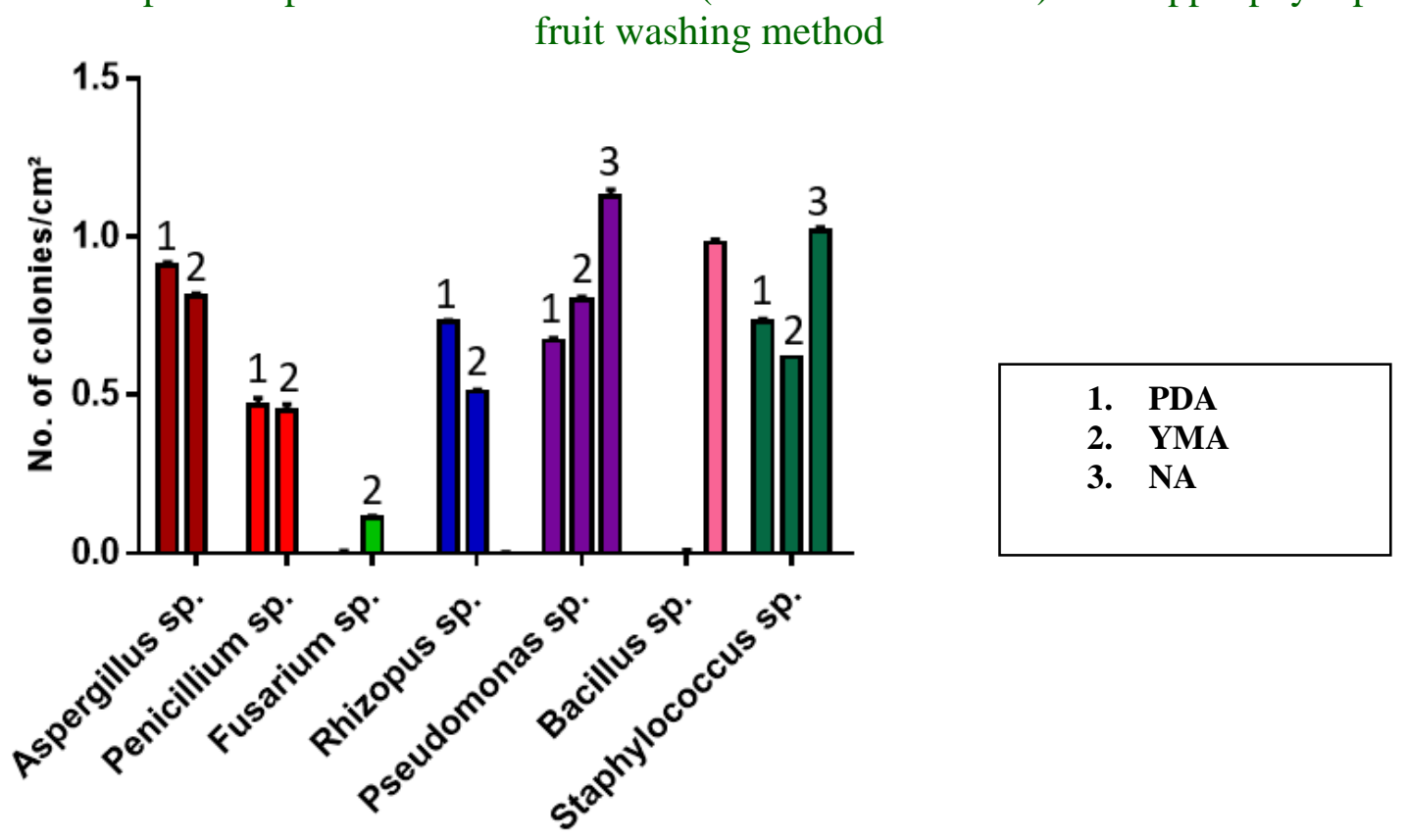

\section{Microbial isolates}

There are very few studies on the epiphytes of apple and their role in the management of postharvest diseases of apple. The present investigation was, therefore, aimed at isolation and estimation of predominant epiphytes from apple leaves and fruits.

Five fungal epiphytes viz., Aspergillus sp. $\left(\mathrm{I}_{1}\right)$, Penicillium sp. ( $\left.\mathrm{I}_{2}\right)$, Fusarium sp. $\left(\mathrm{I}_{3}\right)$, Rhizopus sp. ( $\left.\mathrm{I}_{4}\right)$ and Alternaria sp. $\left(\mathrm{I}_{5}\right)$ and six bacterial epiphytes viz., Pseudomonas sp. ( $\left.\mathrm{I}_{6}\right)$, Pseudomonas sp. ( $\left.\mathrm{I}_{7}\right)$, Bacillus sp. $\left(\mathrm{I}_{8}\right)$, Bacillus sp. ( $\left.\mathrm{I}_{9}\right)$, Staphylococcus sp. $\left(\mathrm{I}_{10}\right)$ and Micrococcus sp. $\left(\mathrm{I}_{11}\right)$ were isolated using different techniques viz., leaf impression, serial dilution and fruit washing methods on three different media (potato dextrose, nutrient agar and yeast agar media). The various methods used in this study to quantify the number of propagules/colonies of microbes are only a rough means of estimating the presence of micro-organisms on leaves (Leben, 1971). It takes into account only those microbes which can be washed away from the leaves and grown on media. Similarly, Ogwu and Osawaru (2014) estimated microfloral isolates on healthy leaves of mature okra and examined eight genera of fungi (Rhodotorula, Saccharomyces, Mucor, Trichothecium, Cladosporium, Rhizopus Aspergillus and Penicillium) and six genera of bacteria (Bacillus, Pseudomonas, Micrococcus, Proteus, Staphylococcus, Serratia).

From all the three epiphytes isolation methods highest number of microbial colonies observed was Bacillus followed by Pseudomonas. This investigation shows that apple phylloplane is inhabited by various fungal and bacterial epiphytes. Most predominant microflora were Bacillus and Pseudomonas sp. This is in conformity with Bryk et al., (2004) who isolated two strains of Pseudomonas sp. (B194 and B224) from apple leaves.

\section{Acknowledgement}

I Aqleema Banoo, like to acknowledge Division of plant pathology Skuast-K for providing me the essential necessities that 
were required to conduct this research methodology. I also like to acknowledge the other authors for useful suggestions while preparing the manuscript.

\section{References}

Andrews, J. H. and Harris, R. F., 2000. The ecology and biogeography of microorganisms on plant surfaces. Annual Review of Phytopathology38: 145-180.

Aneja,K. R. 2004.Experiments in Microbiology, Plant Pathology and Biotechnology, New Delhi, India, New Age International Publisher.

Bal, J. S. 2006. Fruit Growing. Kalyani Publishers, New Delhi pp. 305.

Barnett,H. L., Hunter, B. B. 1972. Elustrated genera of imperfect fungi. 3rd edition. Burgess Publishing Co. pp 299.

Bryk, H., Dyki, B., Sobiczewski, P. 2004. Inhibitory effect of Pseudomonas sp. On the development of Botrytiscinerea and Penicillium expansum. Plant Protection Science40: 128-134.

Chowdhry, P. N., Lal, S. P., Nati, M., Singh,D. V. 2000. Identification of plant pathogenic and biocontrol fungi of agricultural importance. Centre of advanced studies in plant pathology, Division of Plant Pathology, Indian Agricultural Research Institute, New Delhi

Holt, J. G., Sneath, P. H. A., Stanley, J. T., Williams, S. T. 1994. Bergeys Manual of Determinative Bacteriology (9th Edn,). Williams and Wilkins, Baltimore, USA.

Janisiewich, W. J.1987. Post-harvest biological control of blue mold on apples. Phytopathology77: 481-485.

Janisiewicz, W. J. and Roitman, J. 1988. Biological control of blue mold and gray mold on apple and pear with Pseudomonas cepacia. Phytopathology78: 1697-1700.
Janisiewicz, W. J., Tworkoski, T. J. and Kurtzman, C. P. 2001. Biocontrol potential of Metchnikowia pulcherrima strains against blue mold of apple. Phytopathology91: 10981108.

Leben, C. 1971. The bud in relation to the epiphytic microflora. In: Ecology of leaf surface microorganisms(Eds. Preece, T. F. and Dickinson, C. H.) London academic Press, pp. 117-127.

Mandhare, V. K. and Suryawanshi, A. V. 2009. Phylloplane microflora of safflower. Agricultural Science Digest 29: 1-2.

Manso, T. and Nunes, C. 2011. Metschnikowia andauensis as a new bio-control agent of fruit postharvest diseases. Postharvest Biology and Technology, 61: 64-7.

Mukhtar, I., Mushtaq, S., Ali, A. and Khokhar, I. 2010. Epiphytic and endophytic phyllosphere microflora of Cassytha filiformis and its hosts. Ecoprint 17: 1-8.

Ogwu, M. C., Osawaru, M. E. 2014. Comparative study of microflora population on the phylloplane of okra (Abelmoschus esculentus). Niger Journal of Biotechnology28: 17-25.

Sobiczewski, P. and Bryk, H. 1995. Bacteria for control of postharvest diseases of fruits. In: Environmental Biotic Factors in Integrated Plant Disease Control (Eds. M. Manka).Polish phytopathological society, Poznan, Poland pp.105-111

Sobiczewski, P., Bryk, H., Berezynski, S. 1996. Evaluation of epiphytic bacteria isolated from apple leaves in the control of postharvest diseases. Journal of Fruit Ornamental Plant Research 4: 35-45.

Whipps, J. M., Hand, P., Pink, D. and Bending, G. D. 2008. Phyllosphere microbiology with special reference to diversity and plant genotype. Journal of Applied Microbiology 105: 1744-1755.

\section{How to cite this article:}

Aqleema Banoo, Efath Shahnaz, Saba Banday, Rovidha S. Rasool and Taibah Bashir. 2020. Studies on Epiphytic Microflora on Apple (Malus domestica Borkh.) Fruits and Leaves. Int.J.Curr.Microbiol.App.Sci. 9(07): 1802-1810. doi: https://doi.org/10.20546/ijcmas.2020.907.206 